$42^{\circ}$ Convegno Internazionale dei Docenti delle Discipline della Rappresentazione Congresso della Unione Italiana per il Disegno

\title{
Il disegno di restauro
}

\author{
Paolo Giordano
}

Abstract

II disegno di rilievo di un'architettura, per sua intima condizione etimologica, è la raccolta di informazioni metriche necessarie e sufficienti a consentire la rappresentazione grafica bidimensionale o tridimensionale della stessa.

La conoscenza profonda dei caratteri d'identità di un oggetto costruito, sia in relazione alla sua storia e sia in rapporto alle sue particolari peculiarità tipologiche e morfologiche, è perseguibile esclusivamente attraverso un'indagine grafica che sia in grado di svelare anche le criticità connesse al degrado strutturale, materico e linguistico.

Parole chiave

disegno, restauro, degrado, inaccessibile, cimitero.

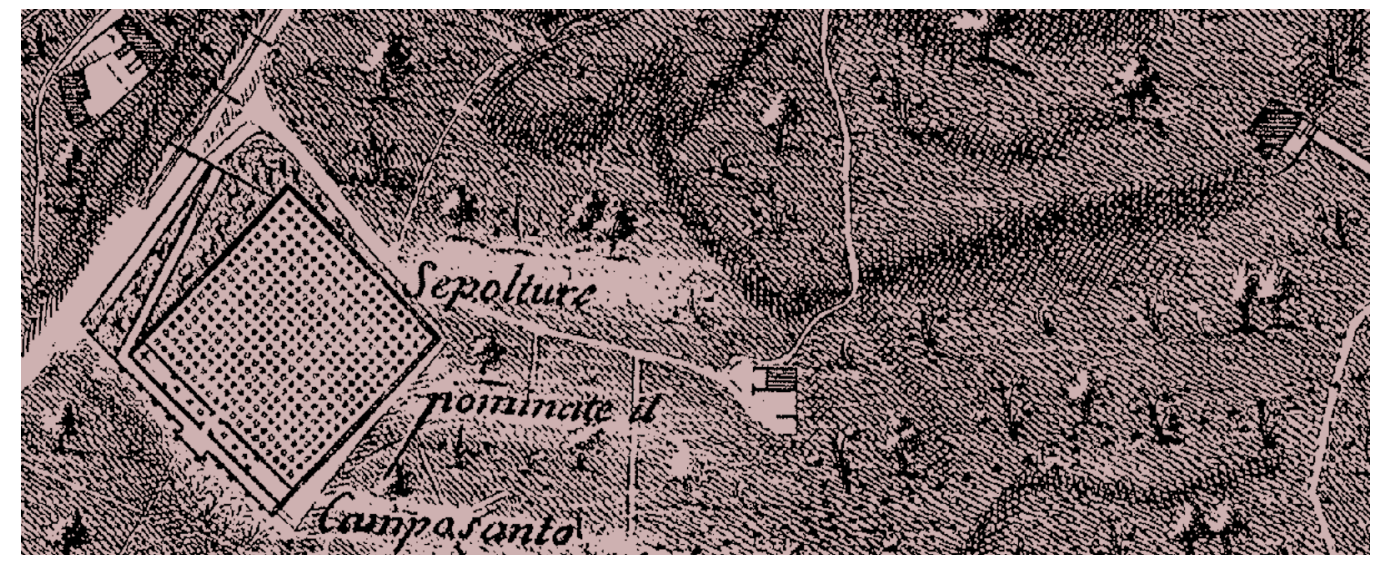




\section{Introduzione}

La conoscenza profonda dei caratteri d'identità di un oggetto costruito, sia in relazione alla sua storia e sia in rapporto alle sue particolari peculiarità tipologiche e morfologiche, è perseguibile esclusivamente attraverso un'indagine grafica che sia in grado di svelare anche le criticità connesse al degrado strutturale, materico e linguistico. In tale prospettiva maggiore è il valore dell'oggetto costruito e più ragguardevole dovrà risultare il processo di conoscenza comprendendo, tra le altre, analisi grafiche in grado di ricostruire analiticamente non solo le diverse fasi di crescita e modificazione che ne hanno contraddistinto la propria identità nel tempo ma, anche e soprattutto, la condizione di conservazione alla data dellindagine intesa come status di efficienza che consente al costruito stesso di essere utilizzato rispetto alle proprie contingenti caratteristiche architettoniche.

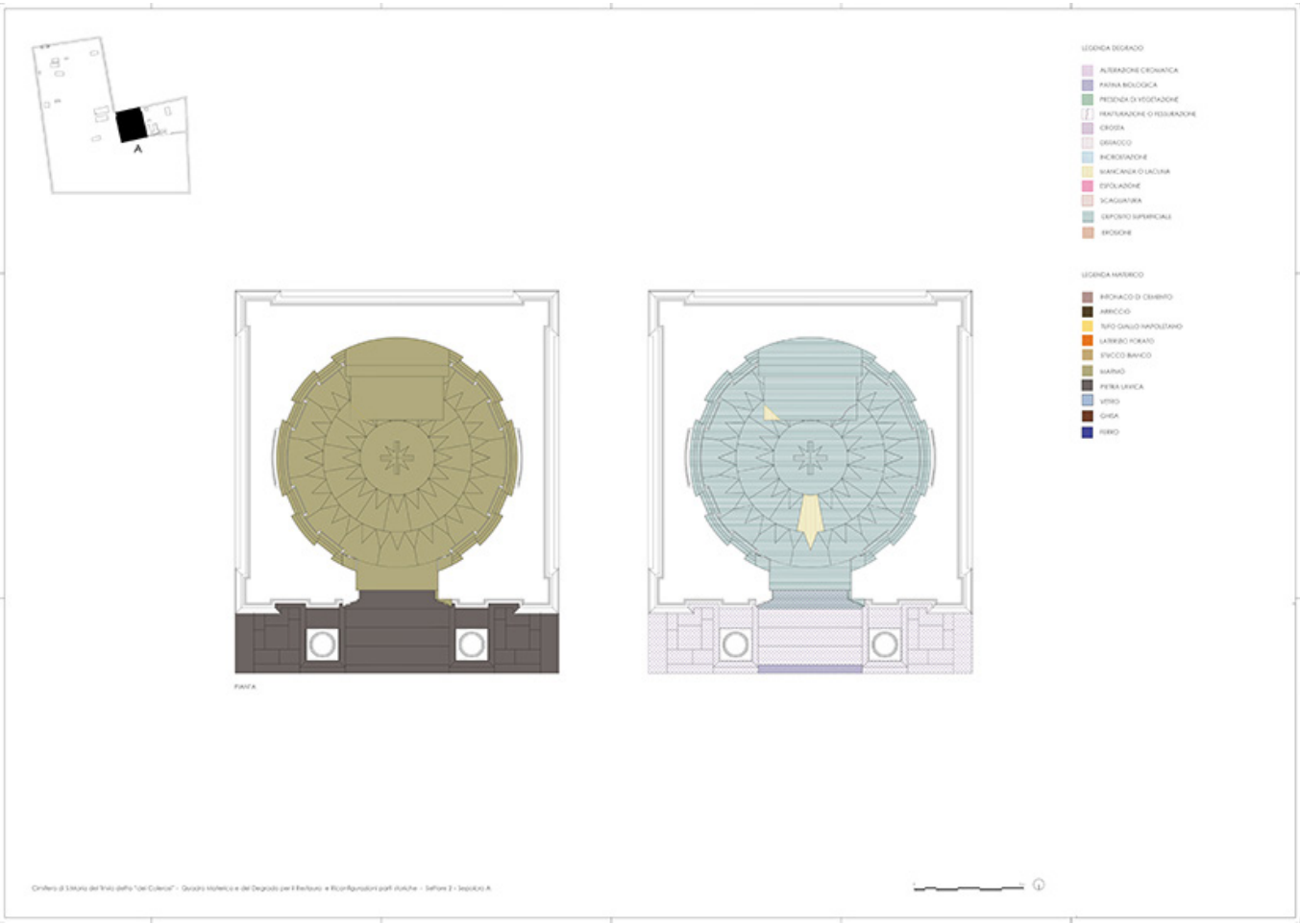

\section{Dal disegno di rilievo al disegno di restauro}

Il disegno di rilievo di un'architettura, per sua intima condizione etimologica, è la raccolta di informazioni metriche necessarie e sufficienti a consentire la rappresentazione grafica bidimensionale o tridimensionale della stessa. Un'acquisizione di informazioni che può essere diretta, fotogrammetrica o digitale e che tende a restituire, solitamente, una raffigurazione dell'architettura rilevata del tutto 'icastica' ovvero contraddistinta da una rappresentazione realistica che documenta graficamente nei tratti essenziali e quindi in modo efficace e asciutto, generalmente con un disegno 'al tratto', l'oggetto costruito indagato. II disegno di rilievo, in generale, si presenta così alla stregua di uno strumento colto che fornisce una conoscenza approfondita dei caratteri metrici e linguistici di un oggetto costruito individuandone le qualità architettoniche specifiche in termini di identità e riconoscibilità propria. Viceversa, il disegno di rilievo per il restauro, insieme alle indagini strumentali, si colloca in una dimensione 'altra' tendente ad approfondire la determinazione della natura o della sede di una criticità dell'architettura in base alla valutazione di uno stato patologico che può manifestarsi sia nei propri elementi strutturali che in quelli estetici. La valutazione della sintomatologia di una o 
Fig. 2. II Cimitero dei Colerici a Napoli. Quadro materico e del degrado. Settore 2. Sepolcro A. Prospetto principale.

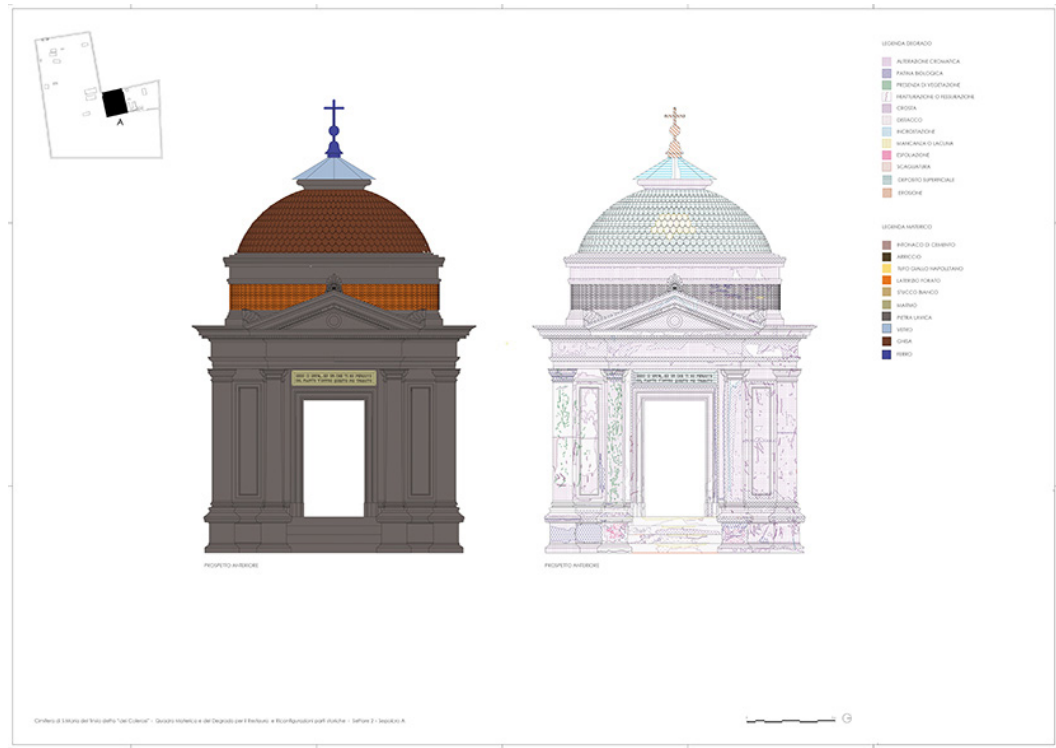

più criticità individuabili in un oggetto costruito comporta anche la successiva elaborazione di una prognosi che può prevedere il decorso operativo da adottare al fine di raggiungere un nuovo equilibrio statico, formale e linguistico dello stesso. II consolidamento, il restauro, la conservazione e valorizzazione dell'architettura si conquista attraverso un apparato grafico complesso che esprime una propria specificità disciplinare di carattere tematico. Si tratta, in buona sostanza, di un ispessimento delle potenzialità documentative che, partendo dal rilievo architettonico dell'opera costruita da analizzare, si esprimono tramite elaborati grafici maggiormente introspettivi che, 'guardando dentro', restituiscono un quadro completo delle sofferenze materiche, strutturali, fisico-chimiche ed estetiche che concorrono al degrado dell'architettura sino, a volte, a una sua possibile e conseguente perdita di testimonianza reale, per crollo parziale o collasso improvviso e rovinoso, come opera fisica materiale e concreta collocata nello spazio urbano o in quello paesaggistico e territoriale. La condizione di preesistenza di un oggetto costruito, da indagare attraverso lo strumento critico del rilievo, presuppone una forte interrelazione tra le discipline del disegno della storia e del restauro attraverso raffigurazioni in grado di produrre elaborati grafici dotati di un'ogget-

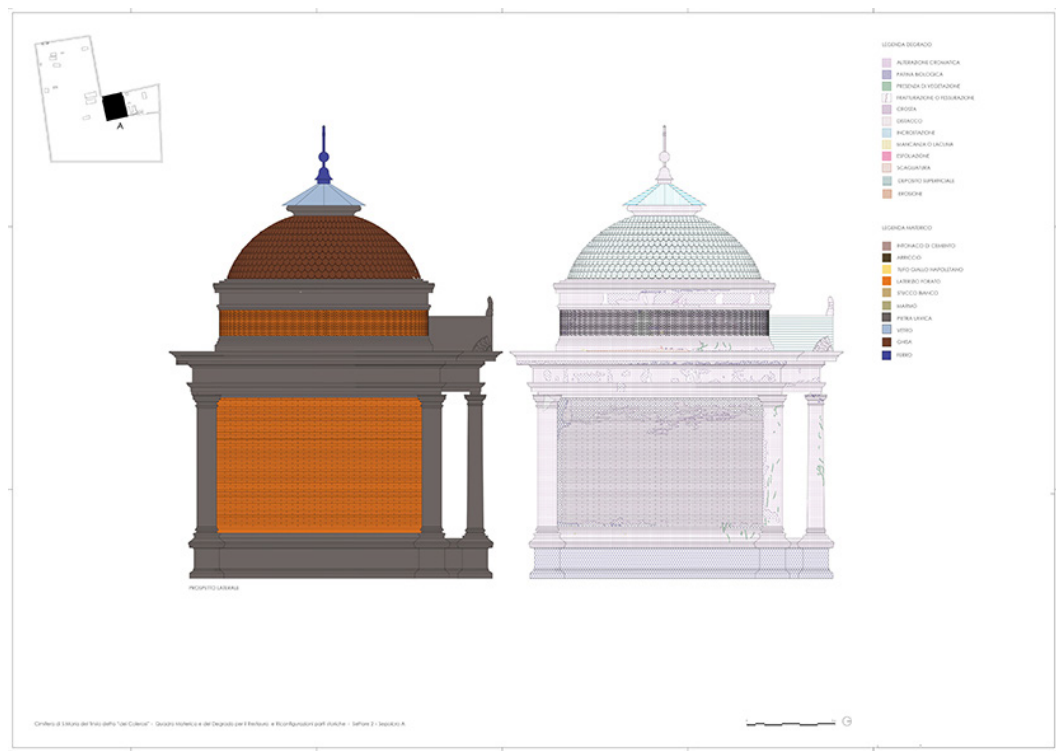


tiva caratterizzazione documentativa. Maggiore sarà il livello di scientificità rintracciabile nel disegno di restauro e più rilevante risulterà la caratterizzazione soggettiva dello stato di conservazione dell'oggetto costruito da analizzare ai fini della salvaguardia e preservazione delle sue qualità materiche, strutturali ed estetiche. Nello specifico, i disegni di rilievo 'scientifico' che forniscono un primo quadro della sintomatologia architettonica di un'architettura degradata sono individuabili, innanzitutto, nella trilogia tematica rappresentata dal rilievo del degrado, da quello materico nonché da quello cromatico che rappresentano la prima fase documentativa del processo conoscitivo; inoltre dal rilievo del quadro fessurativo capace di introitare le specificità rappresentative del disegno tecnico restituendo così grafici di analisi verificabili (sintetici e diagrammatici) relativi alle criticità strutturali che anticipano i disegni relativi alle fasi di pre-consolidamento e consolidamento e, infine, a quei grafici propositivi che, costruendosi sui precedenti resoconti analitici e tematici, individuano l'ultima fase corrispondente al vero e proprio disegno progettuale di restauro che è pur sempre, un disegno di rilievo 'scientifico' ispessito e irrobustito dalle soluzioni progettuali proposte. In tal senso, premesso che gli scambi tra il progetto di restauro e le idee si attuano attraverso il disegno "che focalizza i lampi dell'intelletto" [Scolari 1982], si deve riconoscere che il rapporto tra gli elaborati grafici, di rilievo e di progetto, e un'opera costruita a essa legati come elaborazione successiva è molto complesso. É un rapporto estremamente articolato che vive e si forma su momenti distinti di un processo conoscitivo e logico assieme che si attua per fasi successive a volte anche diluite nel tempo, tant'è che è stato osservato come a "ogni momento della genesi corrisponde un certo tipo di lavoro" [Negri 1984; 1987] e un tempo di lavoro diverso; in ogni fase del lavoro ci si può servire di un diverso impianto e di conseguenza di un diverso mezzo espressivo che aiuta a decifrare prima e graficizzare poi i caratteri tematici richiesti sia dalla necessaria conoscenza e sia dalla consapevole risposta progettuale inerente il restauro. Decifrazione e graficizzazione che avviene solo in presenza di sé stessi per il tramite di un foglio bianco o di un monitor attraverso cui elaborare i grafici relativi alle diverse questioni tematiche affrontate. In tal modo l'importanza della varie tecniche e raccomandazioni, ad esempio quelle NorMal [ I], da utilizzare nelle successive e diversificate fasi del disegno di restauro, dal primo schizzo a mano libera fino al disegno del particolare tecnico in scala reale ovvero del dettaglio, diventa preponderante rispetto allo stesso progetto, inteso qui come risultato finale di un lavoro grafico programmato a priori; è un valore tutto da ricercare in ogni singola fase dell'analisi conoscitiva e, successivamente, in ogni espressione del progetto di restauro dove i vari luoghi grafici, caricandosi di connotazioni simboliche e normative, interagendo tra di loro, influenzandosi a vicenda via via che il lavoro procede,

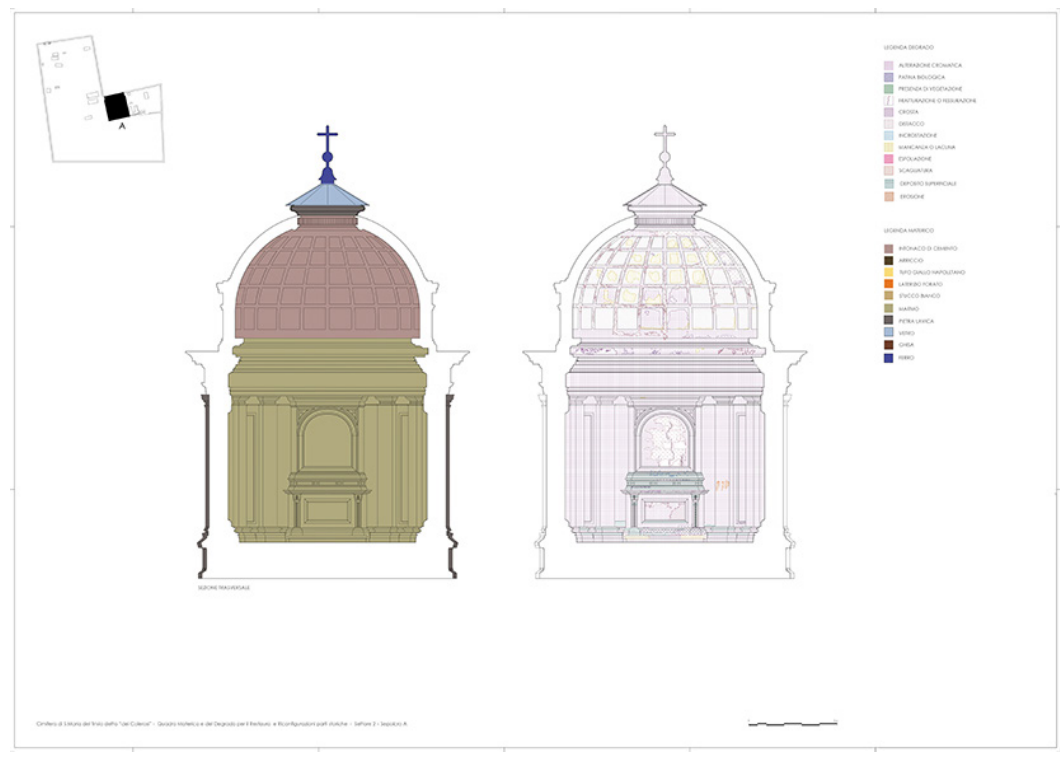


Fig. 5. II Cimitero dei Colerici a Napoli. Quadro materico e del degrado. Settore 8. Sepolcro C.

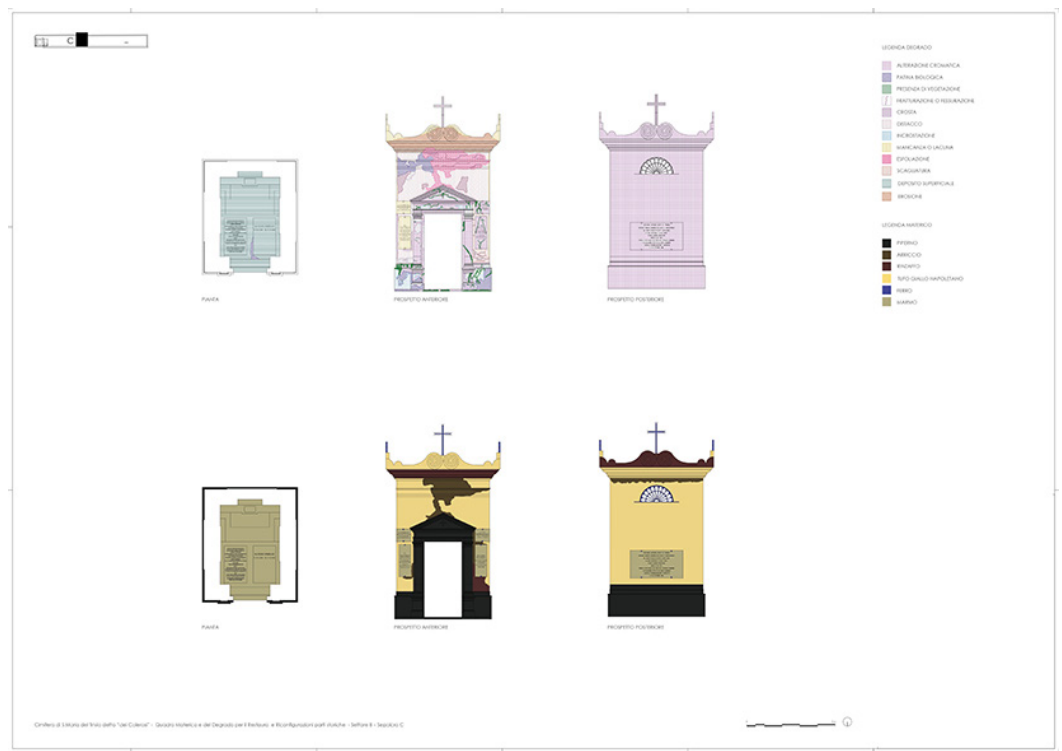

riescono a proporre decisivi approfondimenti tematici che sono determinanti per il prodotto finale. Un prodotto finale inteso come risultante dei vari luoghi del disegno di restauro, di rilievo e di progetto, "da quello autografico dello schizzo a quello allografico [Goodman 2008] del progetto (pianta, sezione e prospetto, assonometria)" capace, in buona sintesi, di "proporre una convincente restituzione delle fasi costruttive e cronologiche dell'edificio, quale indispensabile premessa filologica alla sua lettura storica e figurale" [Carbonara 20 I2]. Un'analisi grafica innanzitutto storica, inoltre scientifica e, infine, linguistica in grado cioè di ridefinire le potenzialità semantiche di ciò che si è perduto a causa del degrado e finalizzata a individuarne, sobriamente, quelle future al di fuori di una semplicistica logica di 'ripristino'. Inserendosi in questa dinamica, il disegno di restauro, oltre a veicolo di cultura nell'evoluzione dialettica, diventa proposta di nuovi assetti configurativi capaci di esprimere non solo il rispetto per la conservazione e valorizzazione dell'esistente ma anche e soprattutto la riconoscibilità oggettiva e contemporanea dello stesso intervento di restauro.

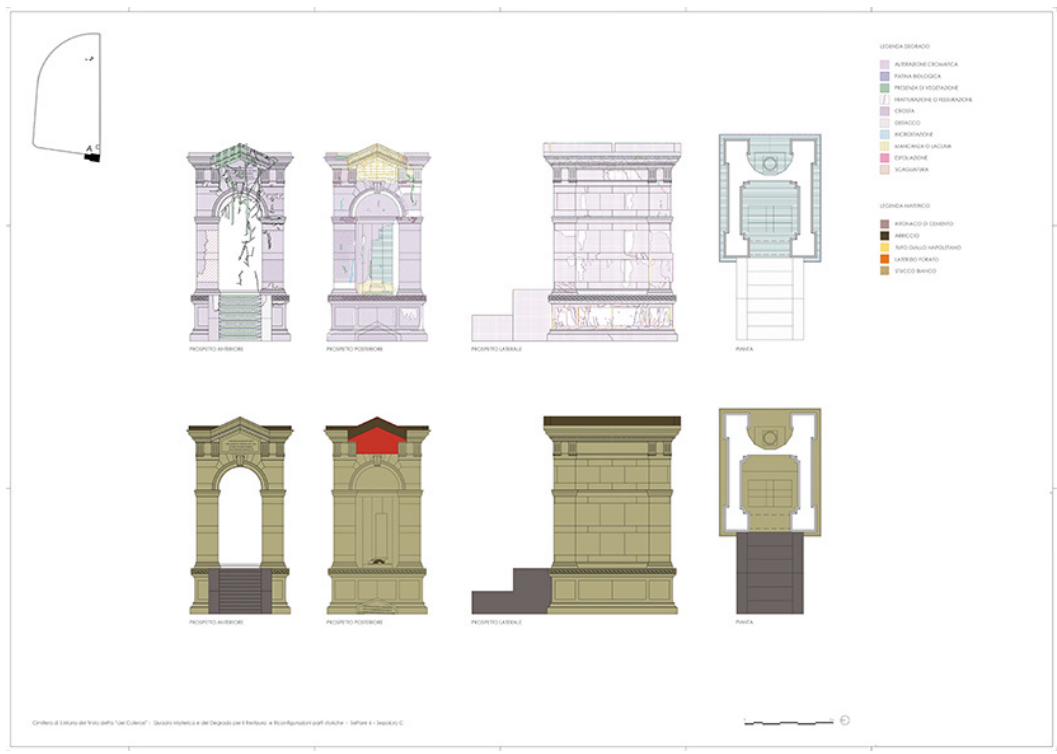

Fig. 6. II Cimitero dei Colerici a Napoli. Quadro materico e del degrado.
Settore 6. Sepolcro C. 


\section{L'inaccessibilità come causa di degrado}

Diverse sono le cause che determinano il degrado dell'architettura: tra le più diffuse l'inaccessibilità risulta essere una delle maggiori criticità che produce la perdita di memoria testimoniale nonché il degrado diffuso di un oggetto costruito. L'inaccessibilità rappresenta, in termini etimologici, tutto quanto, nel mondo sensibile o in quello intellegibile, risulta essere impenetrabile, inconoscibile, inesplorabile, inintelligibile e oscuro. Ovvero tutta una serie di categorie concettuali che interpongono una sostanziale distanza tra le stesse 'cose inaccessibili' e la loro conoscenza sia in termini di valore originario (memoria) che di valore futuro (eredità). In riferimento all'architettura storica e, in generale, ai beni storici la condizione di inaccessibilità si relaziona, innanzitutto alla dimensione dell'oblio, inoltre a quella dell'abbandono e, infine, come conseguenza inevitabile delle prime due, del degrado. Consequenzialità logica di tale catena di disvalori è quello che Platone definiva come noumeno ovvero una specie intellegibile o sensibile che non può essere percepito nel mondo tangibile ma a cui si può arrivare solo tramite il ragionamento. Immanuel Kant individuava, invece, il noumeno alla stregua dell'essenza pensabile, ma inconoscibile, della realtà in sé, quindi, come ciò che pensiamo esistente ma non sperimentiamo proponendosi così come un vero e proprio limite della conoscenza umana. Ma Kant riprende anche l'aspetto positivo insito nella concezione platonica intendendo cioè il noumeno come il sovrasensibile, l'incondizionato che si rivela alla ragion pratica e alla coscienza morale. Condizione quest'ultima che consente di formulare una riflessione sul concetto di inaccessibilità intesa come duplice vulnerabilità dell'architettura costruita: owero, da una parte, quella vulnerabilità degli oggetti architettonici inaccessibili generata dall'abbandono, manifestantesi nel degrado delle proprie caratteristiche strutturali/ materiche e linguistico/estetiche, e, dall'altra parte, una vulnerabilità intesa come perdita di valori testimoniali sottratti alle future generazioni. In tal senso tutte quelle architetture inaccessibili rappresentano un deposito di valori che esiste ma che la nostra contemporaneità non percepisce e che, potenzialmente, il futuro remoto potrà non percepire più. Maggiormente si protrae l'inaccessibilità e in maggior misura si consumano i valori connessi alla loro matericità e alla relativa memoria collettiva. La disciplina del Restauro dell'Architettura assolve un ruolo importante nella rigenerazione e valorizzazione dell'architettura storica abbandonata e degradatasi in conseguenza dell'inaccessibilità: riconosciuto questo supremo valore del restauro non bisognerebbe però mai disgiungerlo da una prospettiva

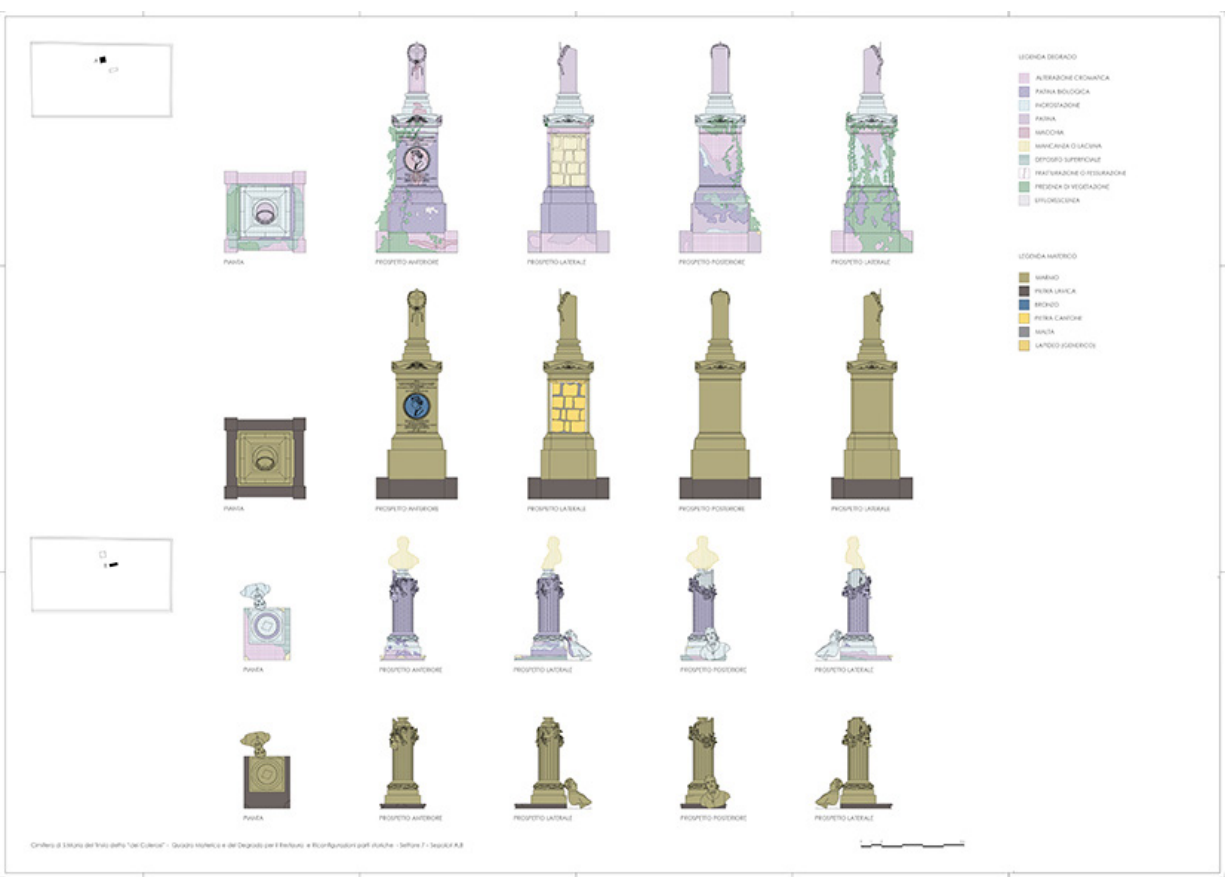



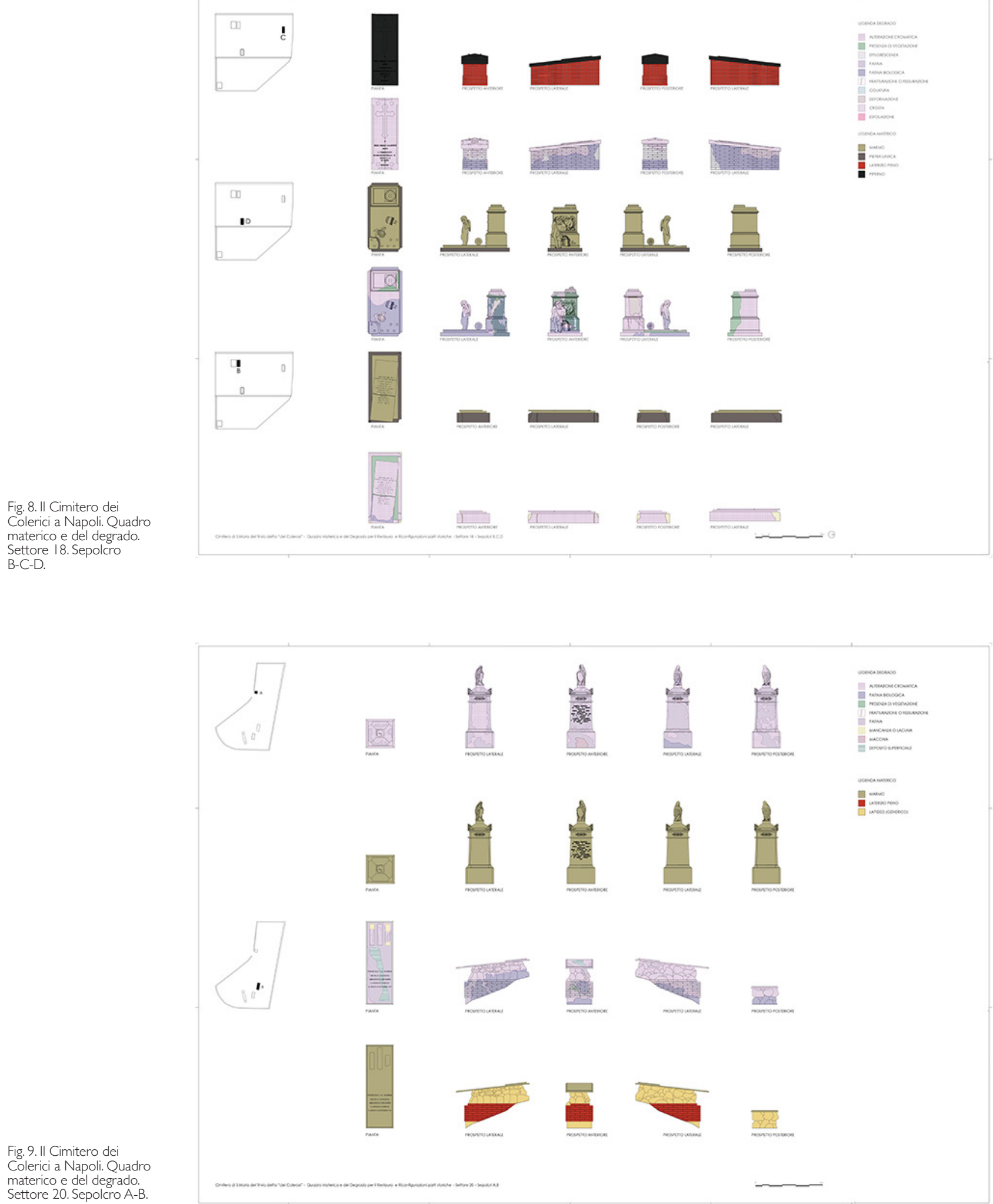
etica capace cioè di ispessirne senso e significato in connessione alla sua intima propensione ovvero quella di rappresentare un crogiuolo di valori immanenti volti a una trascendenza che si riflette sia nella consapevolezza di un passato che non è più e sia in una necessità di un futuro che non è ancora. A fronte di tale necessità si sottolinea l'indispensabilità del disegno di restauro e del rilievo 'scientifico', così come sottolineato precedentemente, intesi alla stregua di strumenti colti della conoscenza e finalizzati alla lettura profonda di tutti quegli aspetti che concorrono a chiarire le reali potenzialità di un nuovo equilibrio strutturale, materico e linguistico in grado di coniugare passato e futuro in una prospettiva critica relazionata alla contemporaneità. Operazione quest'ultima supportata non solo da una prospettiva teorica ma anche e soprattutto dalla messa in campo di tutti quegli strumenti forniti dalla tecnologia contemporanea per la costruzione di un 'territorio intelligente ed eticamente recettivo' alle necessità dell'oggi e del domani. In questo studio il contesto fisico geografico entro cui sperimentare sia la propositività del disegno di restauro e sia le potenzialità di un territorio intelligente ed eticamente recettivo è individuato in due architetture funebri ubicate sulla collina cimiteriale di Poggioreale che risultano essere inaccessibili, dimenticate e degradate, ovvero prossime a quel punto di non ritorno ove si disperde memoria collettiva e coscienza civile. Trasformare l'inaccessibilità in accessibilità significa produrre memoria, riuso e valorizzazione. Significa modificare ambiti architettonici e paesaggistici monumentali inaccessibili rendendoli partecipi alla vita della città individuando funzioni capaci di offrire nuovo valore nonché nuovo senso e significato per un nuovo modo di vivere lo spazio urbano del domani. Una offerta riparatrice da offrire alle future generazioni già individuate oggi come generazioni vulnerabili per i lasciti nefasti della contemporanea società dei consumi. II Cimitero delle 366 fosse [2] e del Sepolcreto dei Colerici [3] rappresentano i capisaldi tipologici relativi ai principali spazi funebri inaccessibili della collina cimiteriale di Poggioreale a Napoli. Spazi che, recentemente, hanno subito consistenti processi modificativi sia in senso positivo che negativo, rendendo necessaria una nuova campagna di approfondimento conoscitivo in grado di aggiornare precedenti ricerche condotte in seno alle competenze disciplinari del disegno dell'architettura, verificate e analizzate nell'ambito pratico teorico del restauro architettonico. La nuova campagna di rilevamento architettonico tematico intrapresa recentemente ha consentito, attraverso l'uso di nuove tecnologie, di documentare una fase di passaggio fondamentale per il futuro destino dei due impianti cimiteriali della collina di Poggioreale. I due impianti cimiteriali presentano diffuse criticità analizzate, recentemente,

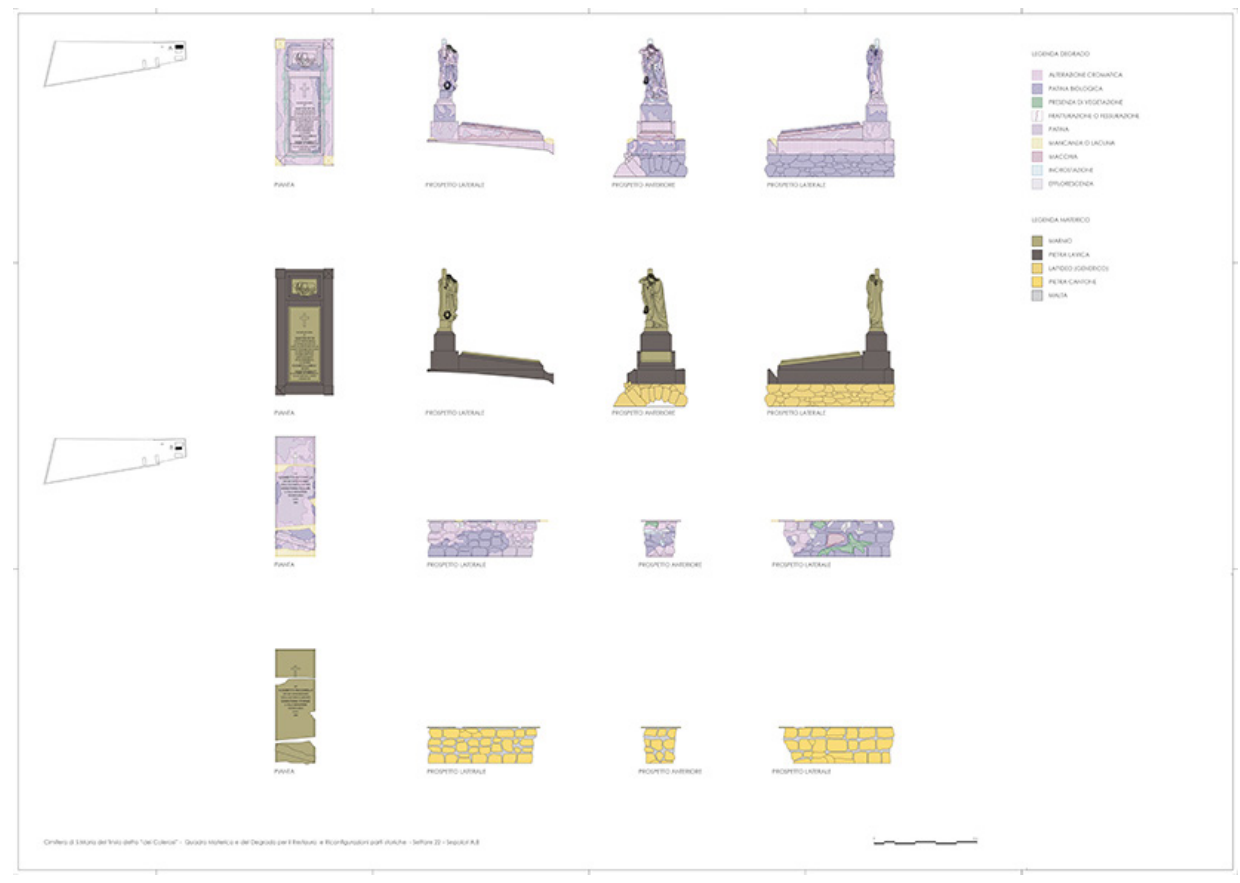


in una prima campagna di indagine analitica che ha consentito di documentare il livello di degrado attraverso un rilievo architettonico e ambientale approfondito successivamente da un rilievo materico, cromatico e del degrado. Tali approfondimenti consentono di chiarire il ruolo del disegno di restauro inteso come strumento colto della conoscenza per la tutela e valorizzazione dei beni culturali. Non solo. I relativi grafici di rilievo di carattere tematico intendono porsi alla stregua di chiare esemplificazioni di quei processi di ispessimento dei tradizionali elaborati grafici e della loro importanza nel disvelamento dei caratteri di identità che, allo stato attuale, raccontano e descrivono la complessità delle diverse fasi storiche che hanno segnato e caratterizzato l'attuale specificità architettonica dei due recinti cimiteriali. Una specificità da restituire attraverso un complessivo disegno di restauro capace di testimoniare, secondo un rigoroso e sobrio atteggiamento documentativo, le diverse fasi modificative che ancora oggi sono percepibili nei due recinti funebri archetipali della collina cimiteriale di Poggioreale.

\section{Note}

[I] Le raccomandazioni NorMaL individuano metodologie di studio unificate e specifiche per il settore della conservazione dei materiali lapidei, nell'ambito dei Beni Culturali.

[2] II Cimitero delle 366 fosse, progettato nel 1762 da Ferdinando Fuga, è un'architettura funebre che, nonostante le numerose manomissioni subite negli ultimi decenni, conserva ancora integra la sua configurazione morfologica originaria definita da un corpo di fabbrica principale, a pianta rettangolare, dietro il quale si apre una corte quadrata recintata da un alto muro originariamente decorato da nicchie intervallate da doppie paraste. É questo l'ambito architettonico maggiormente degradato sia nella pavimentazione in basolato sul quale si stagliano le 366 pietre tombali del sottostante ipogeo funebre e sia nella trasformazione del muro di cinta decorativo, a nicchie e doppie paraste, che negli ultimi cinque decenni è stato alterato da nuovi loculi mai previsti nel progetto originario di Ferdinando Fuga. Le trasformazioni subite dal cimitero, infatti, seppur gravi e consistenti, non hanno fatto perdere del tutto la qualità architettonica che ne determina la sua specifica caratteristica d'identità sia in relazione al sito di appartenenza e sia rispetto alle altre tipologie funebri presenti sulla collina di Poggioreale. In tale ottica il rilievo architettonico per il restauro della struttura funebre rappresenta una documentazione analitica e conoscitiva capace di "fotografare" il grado di degrado strutturale, formale ed estetico che, allo stato attuale, attanaglia il Cimitero delle 366 fosse. La conoscenza dell'ambiente costruito, infatti, può essere esplicitata solo da un "rilievo delle realtà" capace di far emergere non solo le qualità ma anche le criticità del manufatto settecentesco: cfr. Giordano 2006.

[3] II Sepolcreto dei Colerici che sorge a settentrione del Cimitero delle 366 fosse è, allo stato attuale, caratterizzato da erbe alte e alberi rinsecchiti, lapidi marmoree fratturate e cappelle funerarie depredate, sentieri sconnessi e viali deteriorati, muri tufacei disgregati e intonaci ammalorati, sculture deturpate e affreschi degradati. Si tratta di un ambito, architettonico e vegetazionale, monumentale - progettato nel 1837 da Leonardo Laghezza e successivamente ampliato nel | 864 e I 884 - del tutto decadente e prossimo a quel fatidico punto di non ritorno che finirebbe per cancellare una delle testimonianze monumentali più interessanti della collina cimiteriale di Poggioreale. Per tale ambito è stato elaborato, analogamente all'antistante Cimitero delle 366 fosse, un rilievo tematico del degrado che presuppone al suo irrinunciabile e prossimo restauro architettonico e vegetazionale: cfr. Giordano 2006.

\section{Riferimenti bibliografici}

Carbonara G. (2012). Disegno e documentazione per il restauro: un impegno interdisciplinare. In Disegnarecon, I2, spacial issue.

Giordano P. (2006). Il disegno dell'architettura funebre. Firenze: Alinea Editore.

Goodman N. (2008). Linguaggi dell'arte. Milano: II Saggiatore.

Mingucci (a cura di). Disegnarecon, vol. 5, n. 10, pp. 21-26.

Negri A. (1984). Enciclopedia.Torino: Edizioni Einaudi.

Scolari M. (1982). Rappresentazioni. In G. Ciucci, M. Scolari (a cura di). Rassegna, n. 9.

Autore

Paolo Giordano, Università della Campania “'Luigi Vanvitelli”, paolo.giordano@unicampania.it

Per citare questo capitolo: Giordano Paolo (202I). Il disegno di restauro/The Restoration Drawing. In Arena A., Arena M., Mediati D., Raffa P. (a cura di). Connettere. Un disegno per annodare e tessere. Linguaggi Distanze Tecnologie. Atti del $42^{\circ}$ Convegno Internazionale dei Docenti delle Discipline della Rappresentazione/Connecting. Drawing for weaving relationship. Languages Distances Technologies. Proceedings of the $42^{\text {th }}$ International Conference of Representation Disciplines Teachers. Milano: FrancoAngeli, pp. 765-782. 


\title{
The Restoration Drawing
}

\author{
Paolo Giordano
}

\section{Abstract}

The survey drawing of an architecture, for its intimate etymological condition, is the collection of metric information necessary and sufficient to allow the two-dimensional or three-dimensional graphic representation of the same.

The deep knowledge of the identity characters of a built object, both in relation to its history and in relation to its particular typological and morphological peculiarities, can only be pursued through a graphic investigation that is able to reveal also the criticalities related to structural, material and linguistic degradation.

Keywords

drawing, restoration, degradation, inaccessible, cemetery.

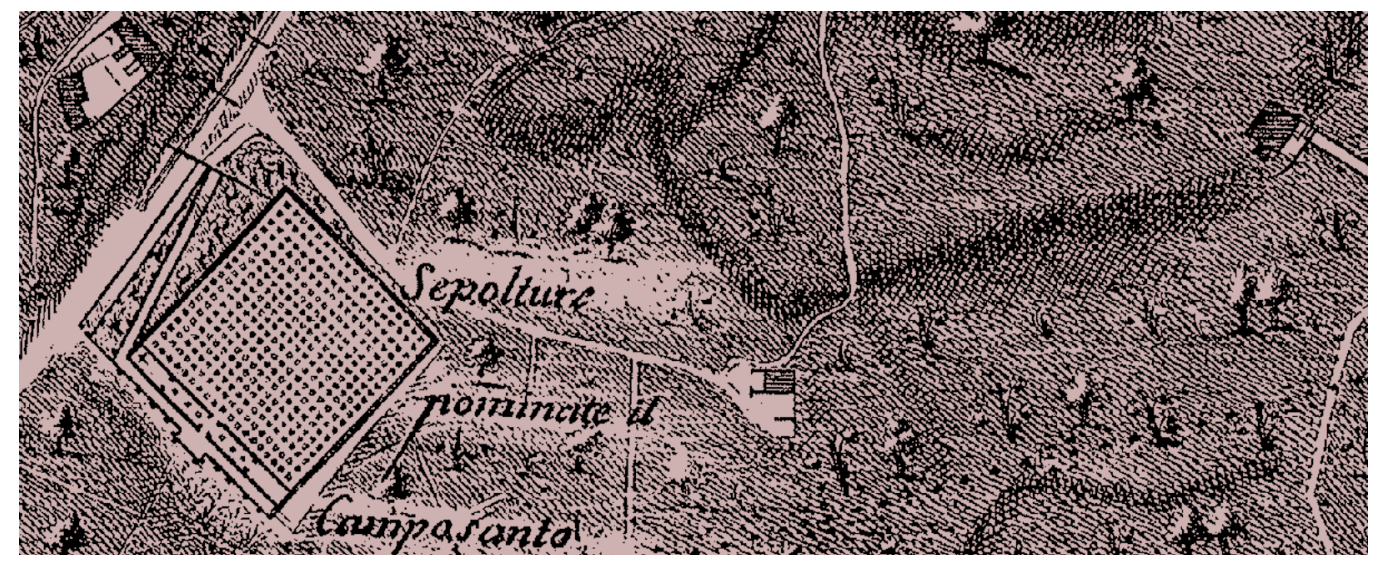




\section{Introduction}

Indepth knowledge of the identity of a built object, both in relation to its history and to its particular typological and morphological characteristics, can only be pursued through a graphic investigation that is also capable of revealing the criticalities connected with structural, material and linguistic degradation. In this perspective, the greater the value of the built object, the more remarkable the knowledge process will have to be, including, among other things, graphic analyses capable of analytically reconstructing not only the various phases of growth and modification that have marked its identity over time but also, and above all, the condition of conservation at the date of the investigation, understood as the status of efficiency that allows the building itself to be used with respect to its contingent architectural characteristics.

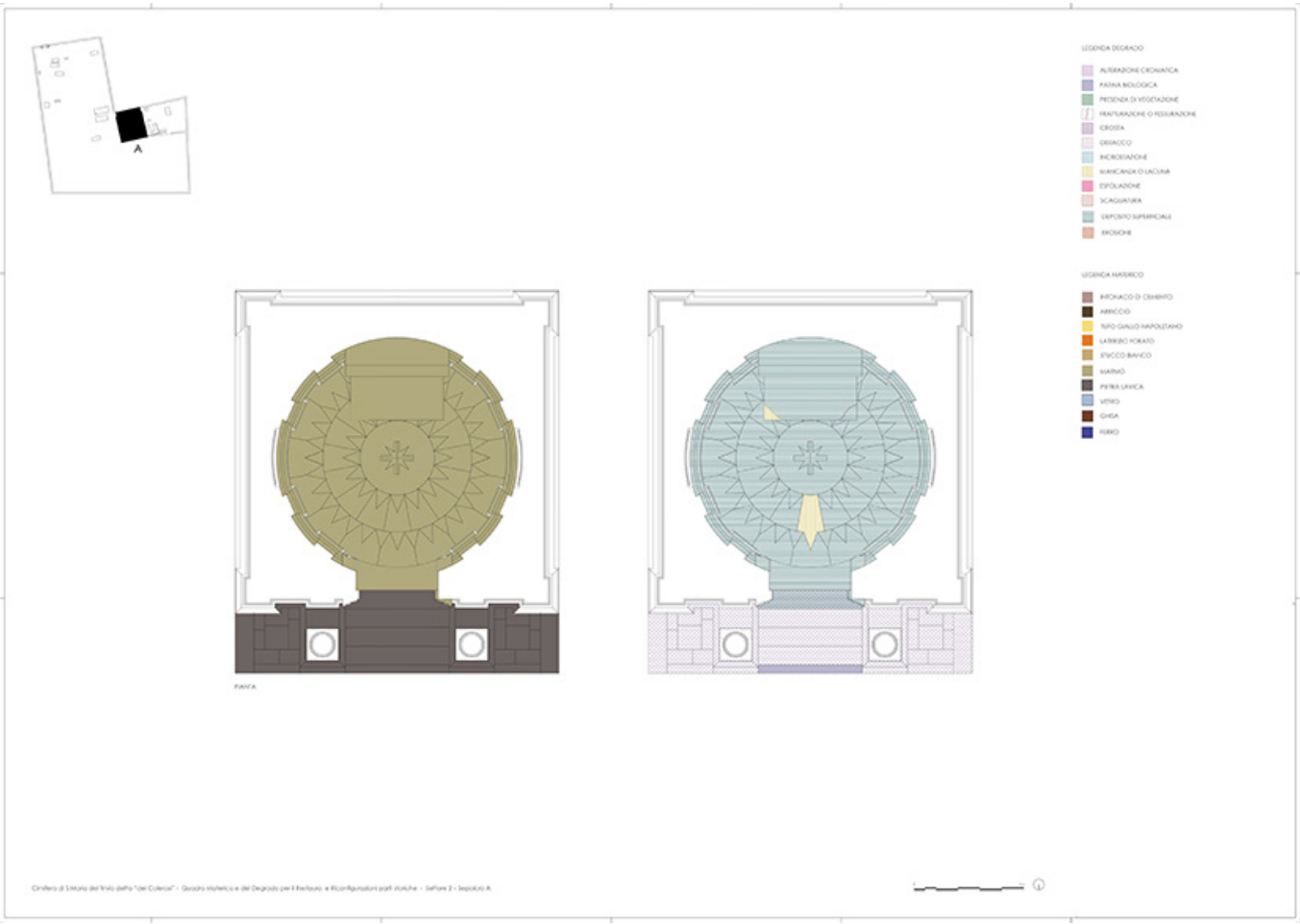

\section{From survey drawing to restoration drawing}

The survey drawing of an architecture, for its intimate etymological condition, is the collection of metric information necessary and sufficient to allow the two-dimensional or three-dimensional graphic representation of the same. An acquisition of information that can be direct, photogrammetric or digital and that tends to return, usually, a representation of the surveyed architecture that is completely 'icastic', that is, distinguished by a realistic representation that graphically documents the essential features and therefore effectively and dryly, generally with a 'line drawing', the built object under investigation. In general, survey drawing is thus a cultured tool that provides in-depth knowledge of the metrical and linguistic characteristics of a built object, identifying its specific architectural qualities in terms of identity and recognisability. The survey design for restoration, together with instrumental investigations, is placed in an 'other' dimension tending to deepen the determination of the nature or location of a criticality of the architecture on the basis of the evaluation of a pathological state that may manifest itself in both its structural and aesthetic elements. The evaluation of the symptomatology of one or more criticalities identifiable in a built object 
Fig. 2. The Colerici Cemetery in Naples. Material and degradation profile. Sector 2. Sepulchre A. Main elevation.

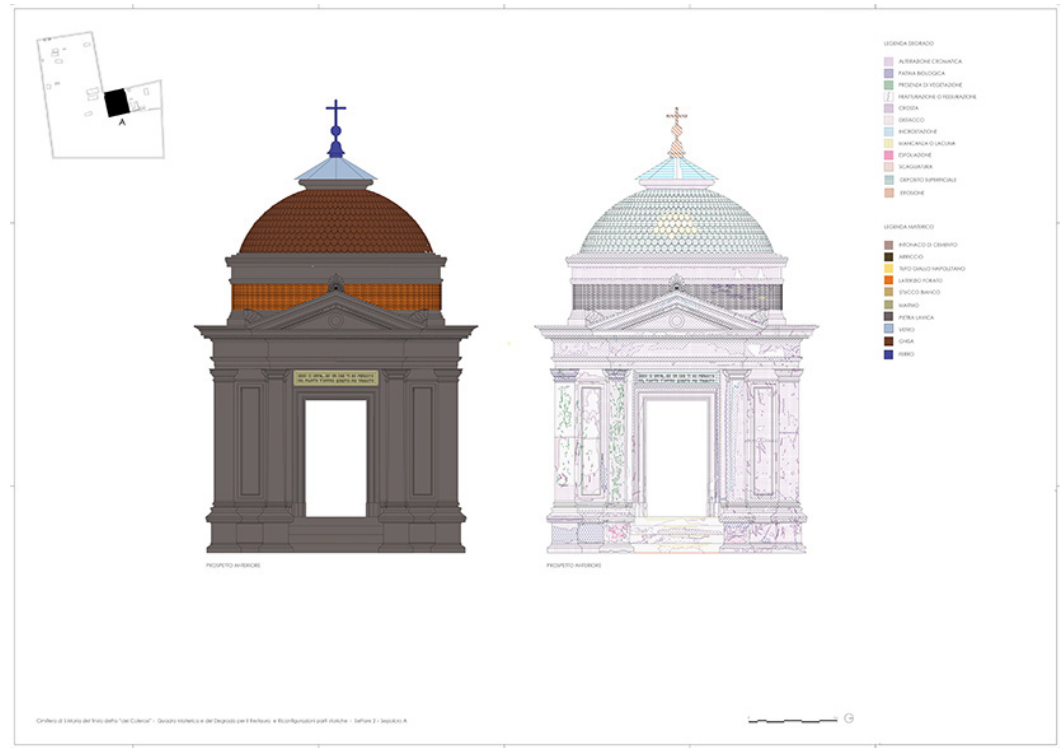

also involves the subsequent elaboration of a prognosis that can foresee the operative course to be adopted in order to achieve a new static, formal and linguistic balance of the same. The consolidation, restoration, conservation and valorisation of architecture is achieved through a complex graphic apparatus that expresses its own disciplinary specificity of thematic character. Basically, it is a thickening of the documentary potential which, starting from the architectural survey of the built work to be analysed, is expressed through more introspective graphic works that, by 'looking inside', give a complete picture of the material, structural, physical-chemical and aesthetic sufferings that contribute to the degradation of architecture, up to, at times, its possible and consequent loss of real testimony, through partial collapse or sudden and ruinous collapse, as a material and concrete physical work located in the urban space or in the landscape and territory. The condition of pre-existence of a built object, to be investigated through the critical instrument of the survey, presupposes a strong interrelation between the disciplines of history drawing and restoration through representations able to produce graphic works with an objective documentary characterisation. The greater the level of scientificity that can be found in the restoration drawing, the

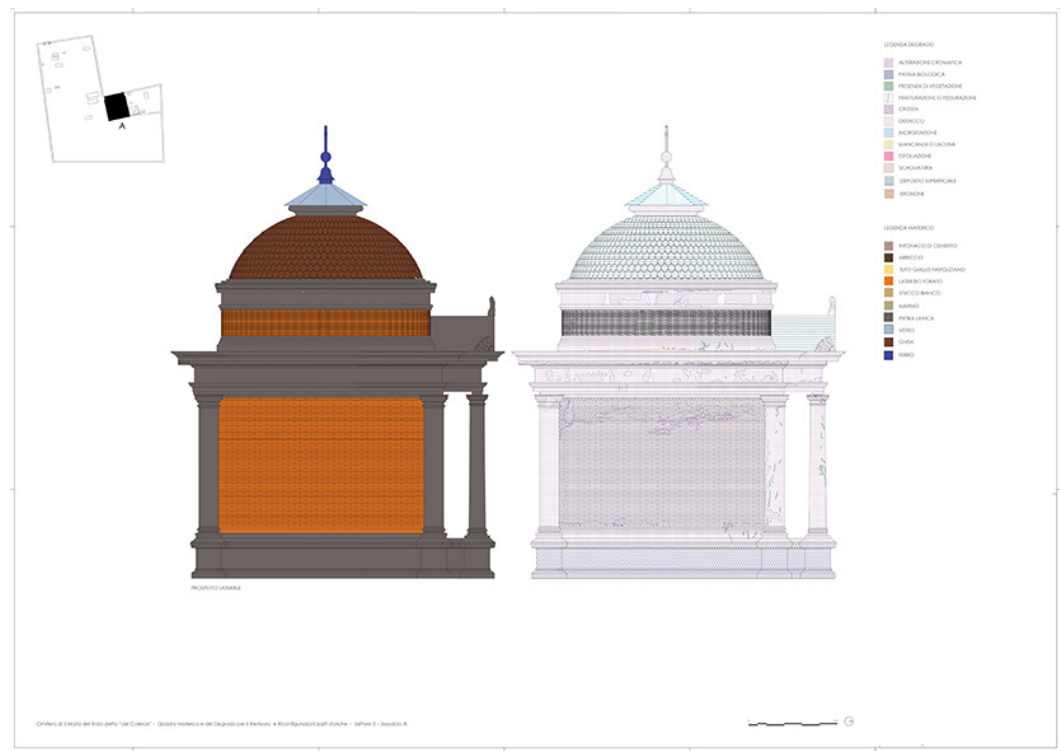


more relevant will be the subjective characterisation of the state of conservation of the built object to be analysed for the purposes of safeguarding and preserving its material, structural and aesthetic qualities. Specifically, the 'scientific' survey drawings that provide an initial picture of the architectural symptoms of degraded architecture are identifiable, first of all, in the thematic trilogy represented by the survey of degradation, the material and the chromatic survey that represent the first documentary phase of the cognitive process; In addition, the survey of cracks that can introduce the representative specificity of the technical drawing, thus returning verifiable analysis graphs (synthetic and diagrammatic) relating to structural criticalities that anticipate the drawings of the pre-consolidation and consolidation phases and, finally, those proposed graphs that, building on the previous analytical and thematic reports, identify the last phase corresponding to the real design of restoration, which is still a 'scientific' design thickened and strengthened by the proposed design solutions. In this sense, given that the exchanges between the restoration project and the ideas are implemented through the drawing "which focuses the flashes of the intellect" [Scolari 1982], it must be acknowledged that the relationship between the graphic drawings, survey and project, and a built work linked to it as a subsequent elaboration is very complex. It is an extremely articulated relationship that lives and forms on distinct moments of a cognitive and logical process that is carried out in successive phases, sometimes even diluted in time, so much so that it has been observed that "each moment of genesis corresponds to a certain type of work" [Negri 1984; 1987] and a different working time; in each phase of the work a different system can be used and consequently a different expressive means that helps to decipher first and then to graphically represent the thematic characters required both by the necessary knowledge and by the conscious design response inherent in the restoration. Deciphering and graphicisation that only takes place in the presence of oneself by means of a blank sheet of paper or a monitor through which one can work out the graphs relating to the different thematic issues addressed. In this way the importance of the various techniques and recommendations, for example those of NorMal [ $I]$, to be used in the successive and diversified phases of the restoration design, from the first freehand sketch to the drawing of the full-scale technical detail, becomes preponderant with respect to the project itself, understood here as the final result of a graphic work programmed in advance; It is a value to be sought in every single phase of the cognitive analysis and, subsequently, in every expression of the restoration project where the various graphic places, loading themselves with symbolic and normative connotations, interacting with each other, influencing each other as the work proceeds, are able to propose decisive thematic insights that are decisive

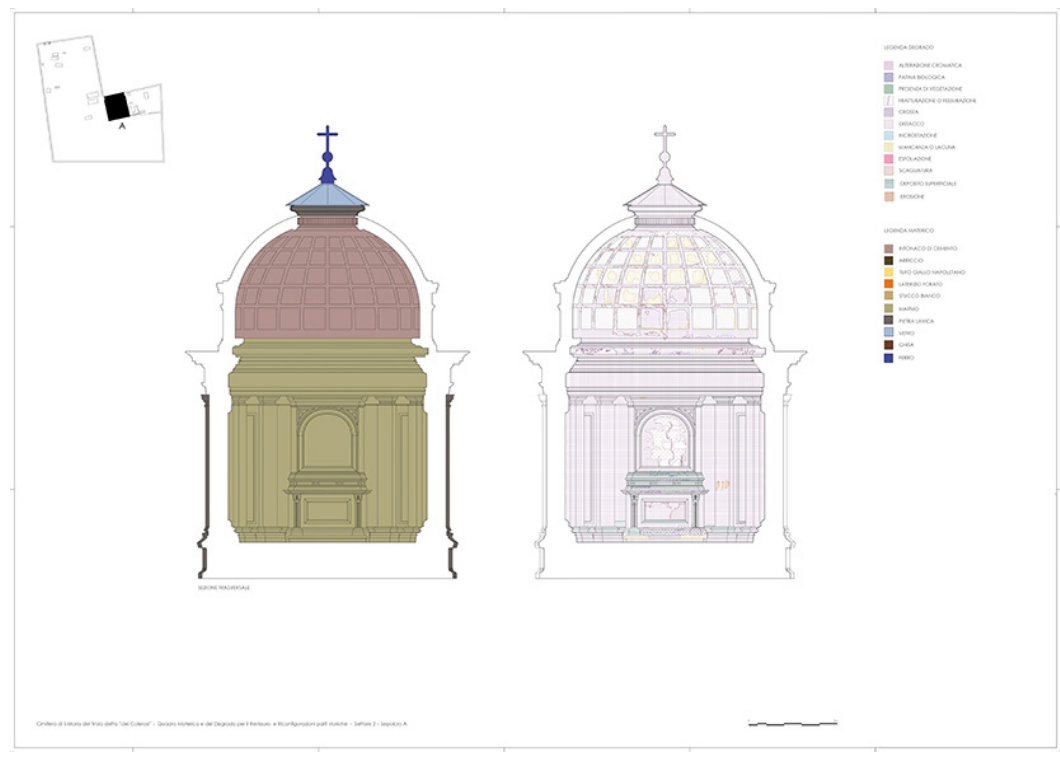




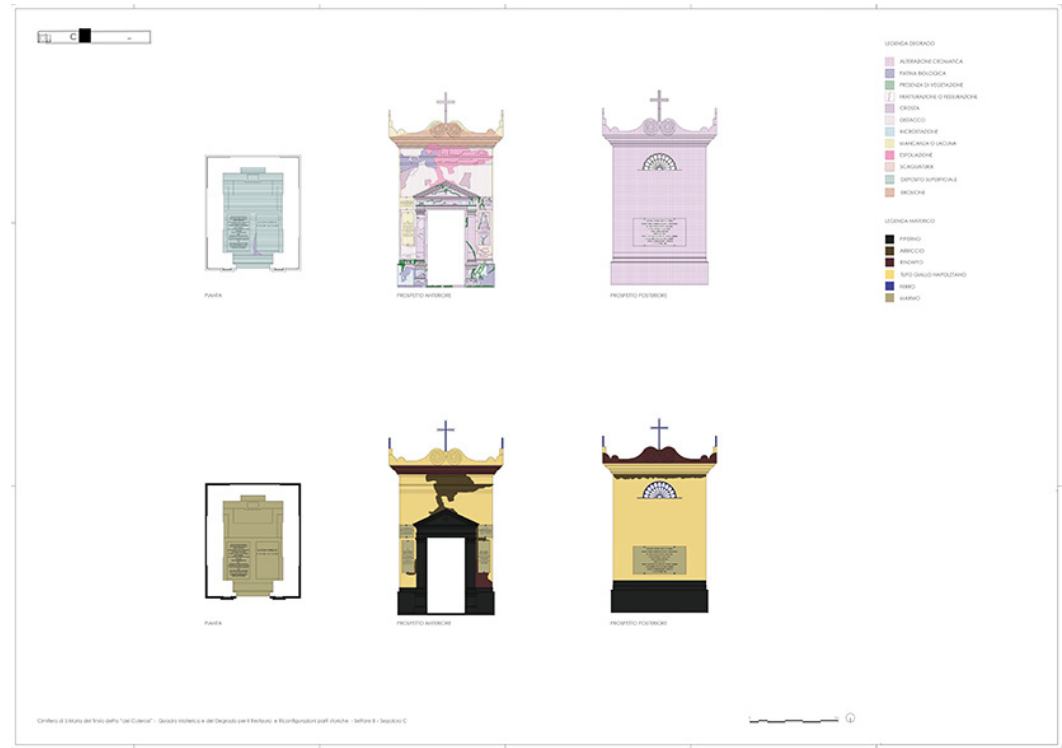

for the final product. A final product intended as a result of the various places of the restoration, survey and project design," "from the autographic one of the sketch to the allographic one [Goodman 2008] of the project (plan, section and elevation, axonometry)" capable, in good synthesis, of "proposing a convincing restitution of the constructive and chronological phases of the building, as an indispensable philological premise to its historical and figurative reading" [Carbonara 2012]. A graphic analysis that is first of all historical, then scientific and, finally, linguistic, capable of redefining the semantic potential of what has been lost due to degradation and aimed at identifying, soberly, the future ones beyond a simplistic logic of 'restoration'. As part of this dynamic, restoration design, as well as being a vehicle for culture in its dialectical evolution, becomes a proposal for new configurative arrangements capable of expressing not only respect for the conservation and enhancement of the existing, but also and above all the objective and contemporary recognisability of the restoration work itself.

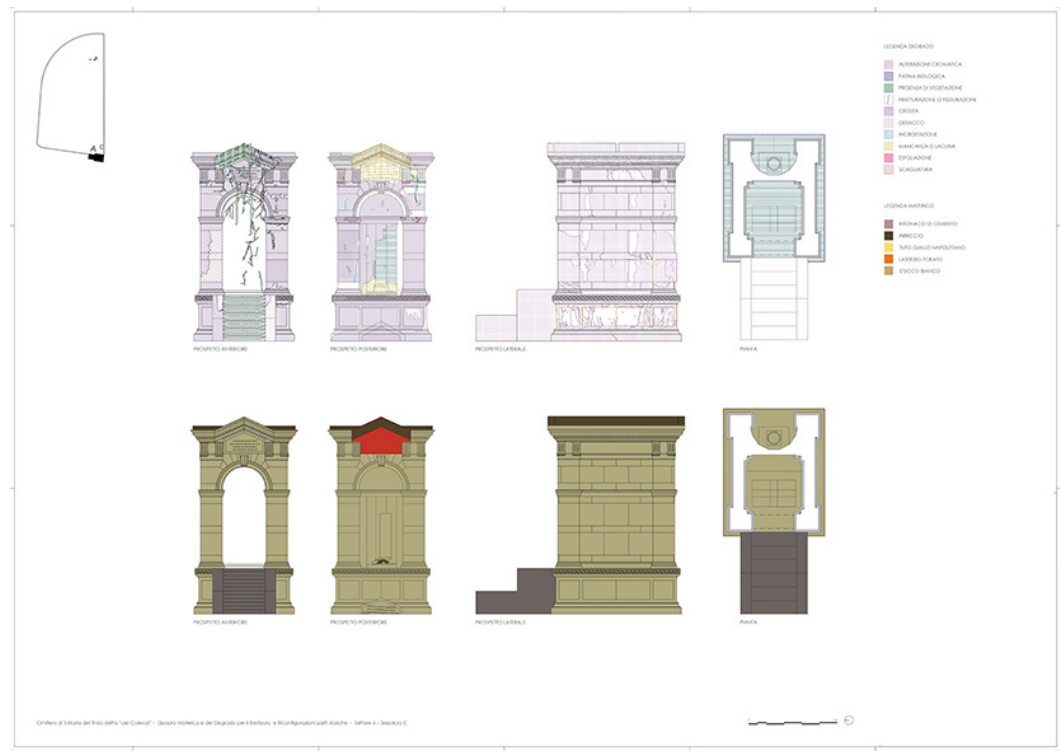




\section{Inaccessibility as a cause of degradation}

Inaccessibility is one of the most widespread causes of the loss of testimonial memory and the widespread degradation of a built object. Inaccessibility represents, in etymological terms, everything in the sensible or intelligible world that is impenetrable, unknowable, unexplored, unintelligible and obscure. That is, a whole series of conceptual categories that interpose a substantial distance between the same 'inaccessible things' and their knowledge both in terms of original value (memory) and future value (inheritance). In reference to historical architecture and, in general, to historical goods, the condition of inaccessibility relates, first of all, to the dimension of oblivion, then to that of abandonment and, finally, as an inevitable consequence of the first two, to degradation. The logical consequence of this chain of disvalues is what Plato defined as noumenon, i.e. an intelligible or perceptible species that cannot be perceived in the tangible world but can only be reached through reasoning. Immanuel Kant, on the other hand, identified the noumenon as the thinkable but unknowable essence of reality in itself, therefore, as what we think exists but do not experience, thus proposing itself as a real limit to human knowledge. But Kant also takes up the positive aspect inherent in the Platonic conception, understanding the noumena as the super-sensible, the unconditioned that reveals itself to practical reason and moral conscience. This latter condition allows us to formulate a reflection on the concept of inaccessibility understood as a double vulnerability of built architecture: that is, on the one hand, the vulnerability of inaccessible architectural objects generated by abandonment, manifesting itself in the degradation of their structural/material and linguistic/aesthetic characteristics, and, on the other hand, a vulnerability understood as the loss of testimonial values taken away from future generations. In this sense, all those inaccessible architectures represent a deposit of values that exists but that our contemporary world does not perceive and that, potentially, the distant future may no longer perceive. The longer the inaccessibility lasts, the more the values connected to their materiality and the relative collective memory are consumed. The discipline of Restoration of Architecture plays an important role in the regeneration and enhancement of historical architecture abandoned and degraded as a result of "inaccessibility': recognized this supreme value of restoration should not, however, never be separated from an ethical perspective that is able to thicken the sense and meaning in connection with its intimate propensity that is to represent a melting pot of immanent values aimed

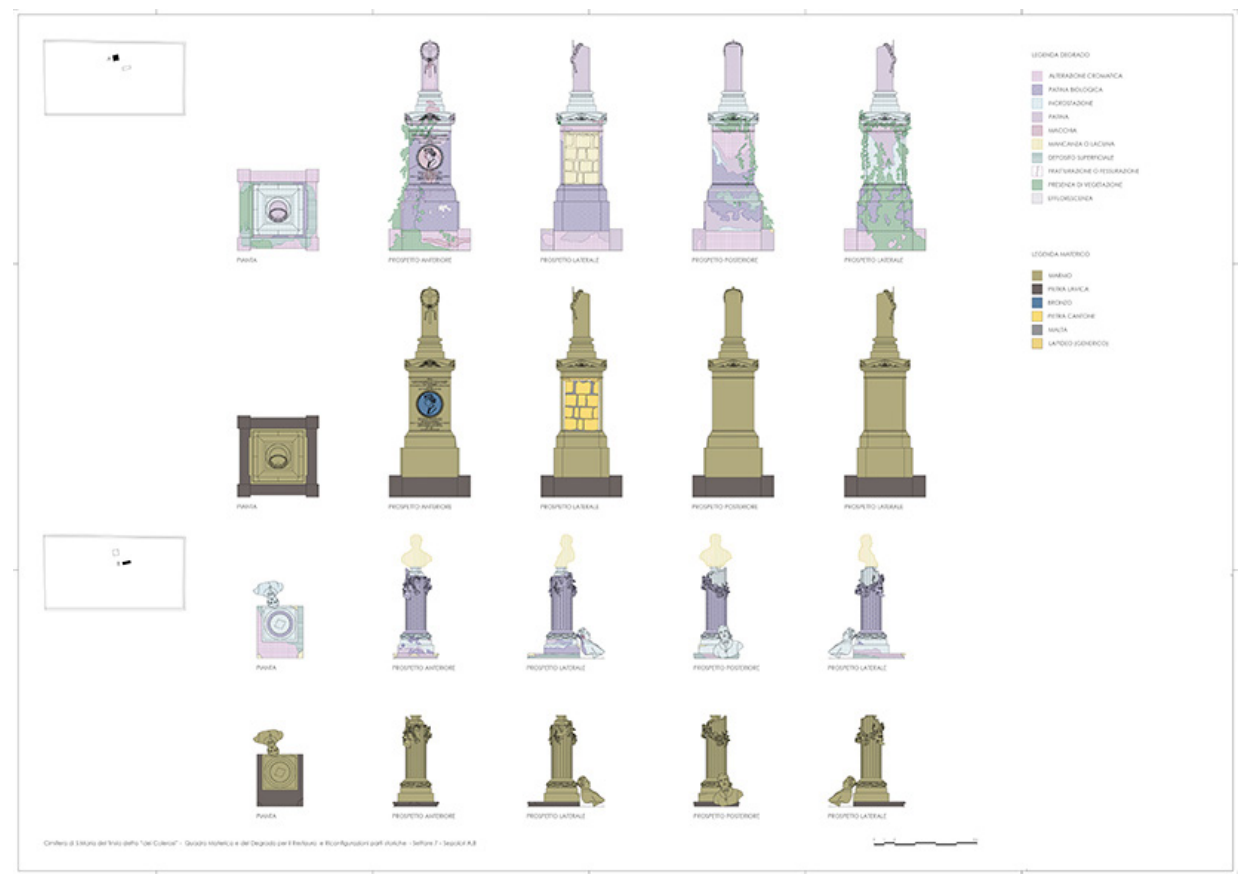



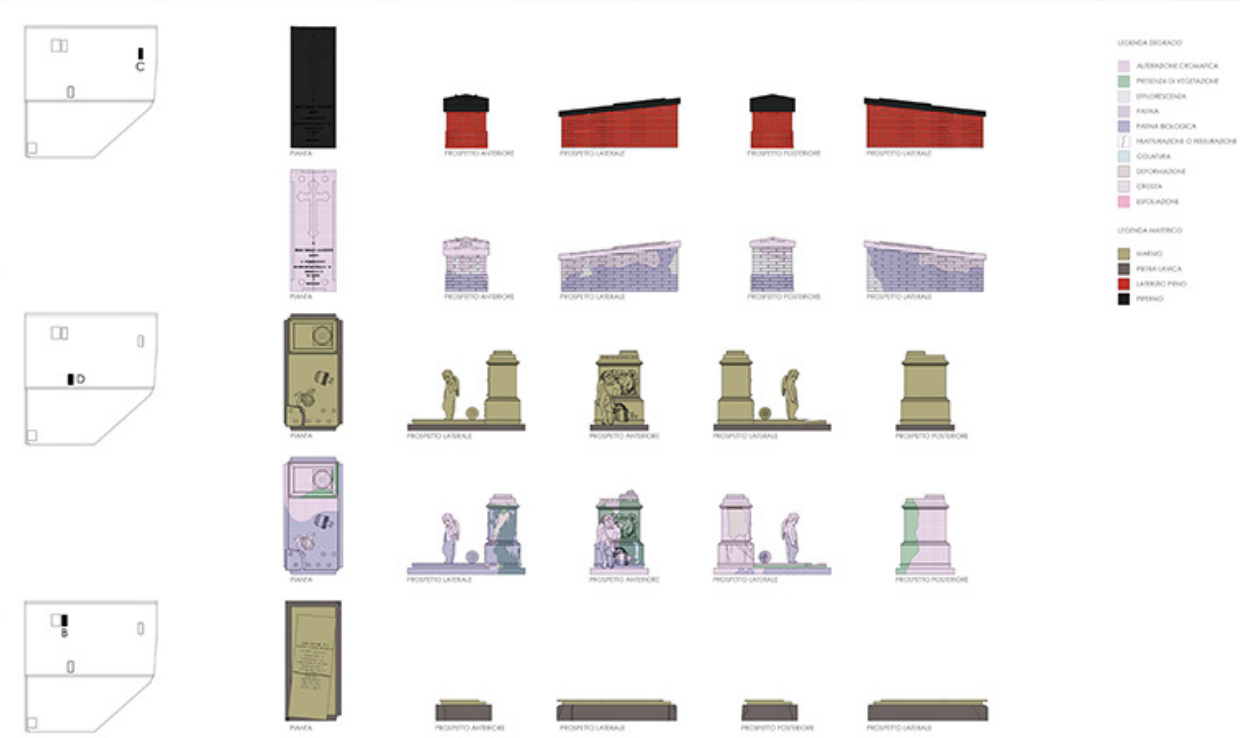

Propulchre B

Fig. 9. The Coleric

Cemetery in Naples.

Material and degradation

profile. Sector 20.

Sepulchre A-B.

ig. I0.The Colerici

Cemetery in Naples.

Material and degradation

picture. Sector 22

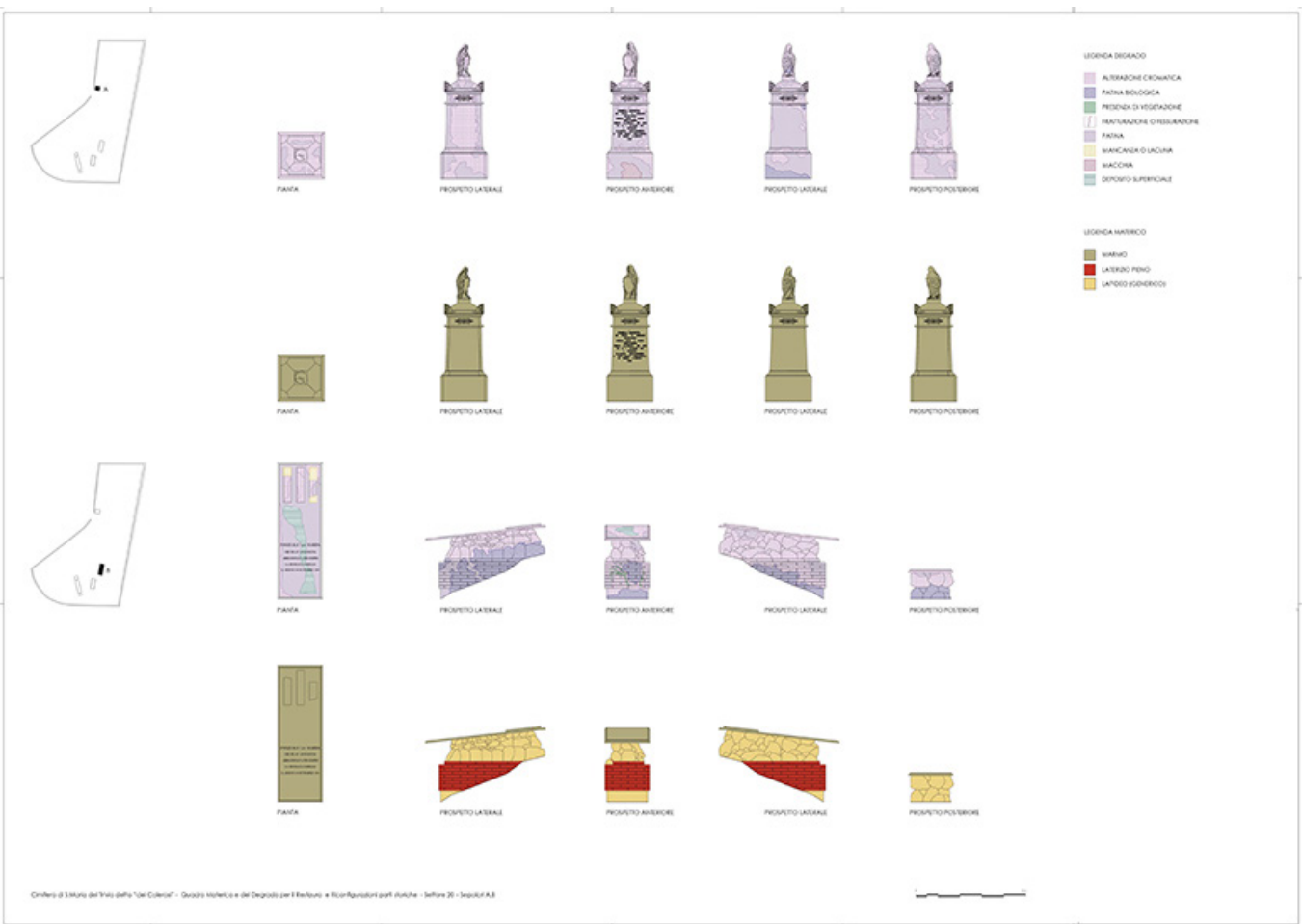


at a transcendence that is reflected both in the awareness of a past that is no longer and in a need for a future that is not yet. In the face of this necessity, the indispensability of the restoration design and the 'scientific' survey, as previously stressed, is underlined, understood as cultured instruments of knowledge and aimed at a profound reading of all those aspects that contribute to clarifying the real potential of a new structural, material and linguistic balance able to combine past and future in a critical perspective related to contemporaneity. This latter operation is supported not only by a theoretical perspective but also and above all by the use of all those tools provided by contemporary technology for the construction of an "intelligent and ethically receptive territory" to the needs of today and tomorrow. In this study, the physical and geographical context within which to test both the propositional nature of the restoration project and the potential of an intelligent and ethically receptive territory is identified in two funerary architectures located on the cemetery hill of Poggioreale, which are inaccessible, forgotten and degraded, close to the point of no return where collective memory and civil conscience are lost. Transforming inaccessibility into accessibility means producing memory, reuse and valorisation. It means modifying inaccessible monumental architectural and landscape areas, making them part of the city's life by identifying functions capable of offering new value as well as new meaning and significance for a new way of experiencing tomorrow's urban space. A restorative offer to be made to future generations, already identified today as vulnerable generations due to the harmful legacies of contemporary consumer society. The Cimitero delle 366 fosse [2] and the Sepolcreto dei Colerici [3] represent the typological cornerstones of the main inaccessible burial spaces on the Poggioreale cemetery hill in Naples. These spaces have recently undergone significant changes, both positive and negative, making it necessary to undertake a new cognitive investigation campaign to update previous research conducted within the disciplinary skills of architectural design, verified and analysed within the theoretical practice of architectural restoration. The new thematic architectural survey campaign undertaken recently has made it possible, through the use of new technologies, to document a fundamental phase in the future fate of the two cemetery facilities on the Poggioreale hill. The two cemetery facilities present widespread criticalities that have recently been analysed in an initial analytical investigation campaign that has made it possible to document the level of deterioration through an architectural and environmental survey, which was subsequently deepened by a material, chromatic and deterioration survey. These in-depth studies make it possible to

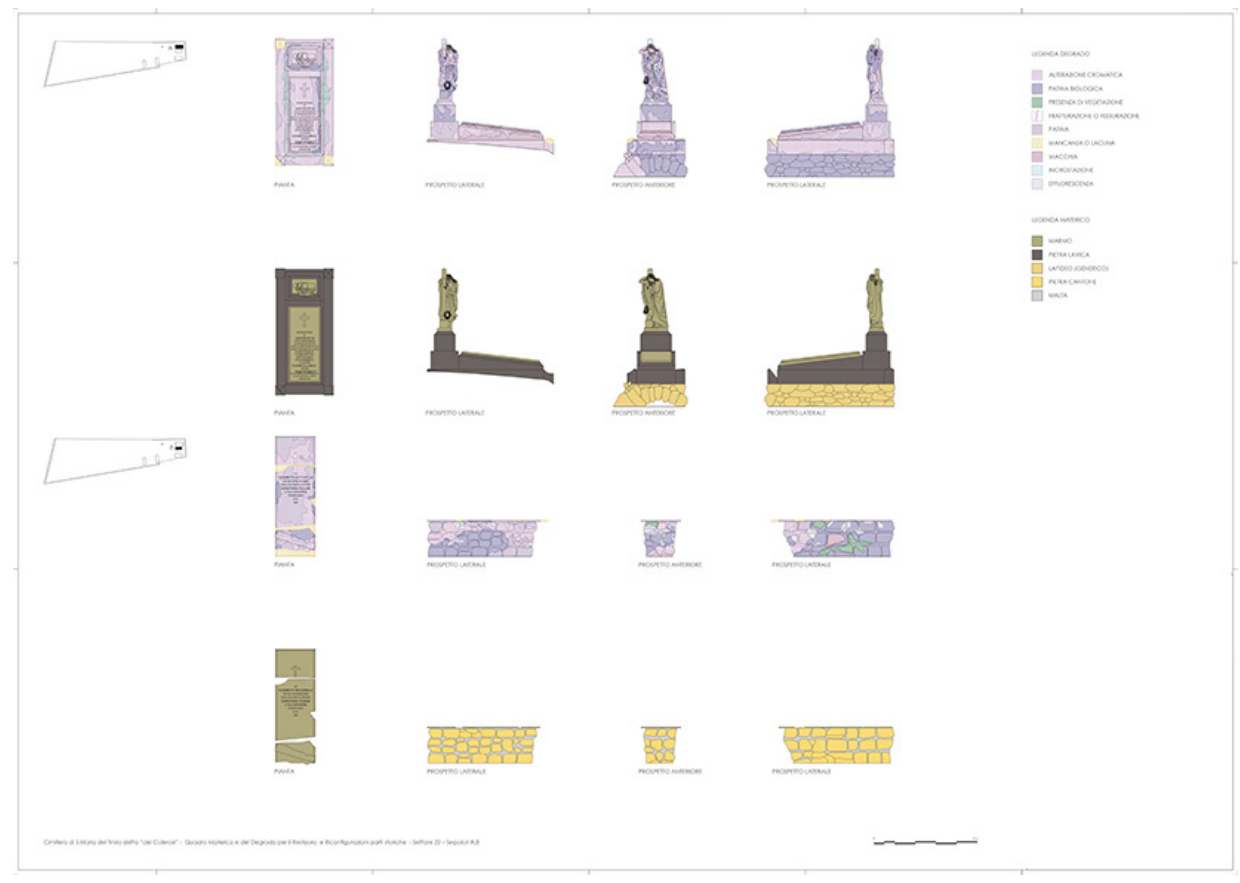


clarify the role of restoration design as a learned tool of knowledge for the protection and enhancement of cultural heritage. Not only. The relative thematic relief graphs are intended to be clear examples of those processes of thickening of the traditional graphic designs and of their importance in unveiling the characters of identity that, at present, tell and describe the complexity of the different historical phases that have marked and characterised the current architectural specificity of the two cemetery enclosures. A specificity to be restored through an overall restoration design capable of bearing witness, according to a rigorous and sober documentary approach, to the different phases of modification that are still perceptible today in the two archetypal funerary enclosures of the Poggioreale cemetery hill.

\section{Notes}

[I] The NorMaL recommendations identify unified and specific study methodologies for the field of stone conservation in the field of Cultural Heritage.

[2] The Cemetery of the 366 pits, designed in 1762 by Ferdinando Fuga, is a piece of funerary architecture which, despite the numerous alterations it has undergone in recent decades, still retains its original morphological configuration, defined by a main rectangular building, behind which is a square courtyard enclosed by a high wall originally decorated with niches interspersed with double pilasters. This is the most degraded architectural area, both in terms of the paving in paving stones on which the 366 tombstones of the underlying funeral hypogeum stand out, and in the transformation of the decorative boundary wall, with its niches and double pilasters, which has been altered over the last five decades by new burial niches that were never envisaged in Ferdinando Fuga's original project. The transformations undergone by the cemetery, although serious and substantial, have not caused it to completely lose the architectural quality that determines its specific identity both in relation to the site to which it belongs and to the other types of burial ground present on the Poggioreale hill. From this point of view, the architectural survey for the restoration of the funeral structure represents an analytical and cognitive documentation capable of "photographing" the degree of structural, formal and aesthetic degradation that currently afflicts the Cemetery of the 366 graves. In fact, knowledge of the built environment can only be made explicit by a "survey of realities" capable of bringing out not only the qualities but also the critical aspects of the eighteenth-century building. Cfr. Giordano 2006.

[3] The Colerici Graveyard to the north of the Cemetery of the 366 pits is currently characterised by tall grasses and withered trees, fractured marble tombstones and despoiled funerary chapels, uneven paths and deteriorated avenues, crumbling tufa walls and deteriorating plaster, defaced sculptures and degraded frescoes. This is a monumental, architectural and vegetational area - designed in 1837 by Leonardo Laghezza and subsequently extended in 1864 and 1884 - which is completely decaying and close to the fateful point of no return that would end up erasing one of the most interesting monuments on the Poggioreale cemetery hill. For this area, as for the Cemetery of the 366 pits in front of it, a thematic survey of the degradation has been drawn up, which presupposes its indispensable and forthcoming architectural and vegetation restoration. Cfr. Giordano 2006.

\section{References}

Carbonara G. (2012). Disegno e documentazione per il restauro: un impegno interdisciplinare. In Disegnarecon, I2, spacial issue.

Giordano P. (2006). Il disegno dell'architettura funebre. Firenze: Alinea Editore.

Goodman N. (2008). Linguaggi dell'arte. Milano: II Saggiatore.

Mingucci (a cura di). Disegnarecon, vol. 5, n. 10, pp. 21-26.

Negri A. (1984). Enciclopedia. Torino: Edizioni Einaudi.

Scolari M. (1982). Rappresentazioni. In G. Ciucci, M. Scolari (a cura di). Rassegna, n. 9.

Author

Paolo Giordano, Università della Campania “'Luigi Vanvitelli”, paolo.giordano@unicampania.it

To cite this chapter. Giordano Paolo (2021). Il disegno di restauro/The Restoration Drawing. In Arena A., Arena M., Mediati D., Raffa P. (a cura di). Connettere. Un disegno per annodare e tessere. Linguaggi Distanze Tecnologie. Atti del $42^{\circ}$ Convegno Internazionale dei Docenti delle Discipline della Rappresentazione/Connecting. Drawing for weaving relationship. Languages Distances Technologies. Proceedings of the $42^{\text {un }}$ International Conference of Representation Disciplines Teachers. Milano: FrancoAngeli, pp. 765-782. 